\title{
The Effect of Work Motivation and Commitment on Teacher Performance
}

\author{
Kasyful Anwar ${ }^{1}$, Rahmi Widyanti ${ }^{2}$, Rabiatul Adawiah ${ }^{3}$, Unut Triyuliadi $^{4}$ \\ 1,2,4 Master of Higher Education Study Program, Faculty of Teacher Training and Education, \\ Islamic University of Borneo, Banjarmasin, Indonesia \\ ${ }^{3}$ Civics Education Department, Faculty of Teacher Training and Education, Lambung \\ Mangkurat University, Banjarmasin, Indonesia \\ Email: rabiatuladawiah@ulm.ac.id
}

\begin{abstract}
Teacher performance needs to be continuously improved because it affects the quality of graduates and the quality of education. It is necessary to conduct research related to what factors can affect teacher performance to improve teacher performance. This study aims to analyze the effect of motivation and work commitment on teacher performance. This study uses a quantitative approach. The sampling technique used in this research is saturated sampling. All members of the population, amounting to 43 people, are used as samples. Data collection was done by using a questionnaire technique. Before the instrument is used, the first instrument is tested to determine its validity and reliability. Technical analysis of the data using simple linear regression test and multiple linear regression using the SPSS version 22 application. From the research results, it is known that (1) motivation has a significant positive effect on teacher performance by $36.1 \%$; (2) commitment has a significant positive effect on teacher performance by $41.0 \%$; (3) simultaneously work motivation and commitment have a positive effect on teacher performance by $50.7 \%$. The conclusion is that the two variables, individually or together, are a determining factor in improving teacher performance.
\end{abstract}

Keywords: Work Motivation, Commitment, Teacher Performance

\section{A. INTRODUCTION}

Teachers have a critical role in educational institutions as strategic leaders and accountable for the quality of education provided on duty, as defined in Government Regulation of the Republic of Indonesia Number 19 of 2017 amending Government Regulation Number 74 of 2008 respecting Teachers. Item 1 The first paragraph of this rule defines a teacher as a professional educator whose primary responsibility is to educate, teach, guide, direct, train, assess, and evaluate pupils in early childhood education, primary education, and secondary education. Teachers constantly strive to improve their abilities to give services to students, the community, and the environment, most notably their work environment, while carrying out instructional activities (Meiliyani, Fitria, \& Puspita, 2021). In the learning process in schools, teachers occupy a significant position and determine the success of education (Widoyoko, 2012; Anwar et al., 2021).

Regarding the critical role of teachers in student success in learning, the results of Sudjana's research (Widoyoko, 2012) show that $76.6 \%$ of student learning outcomes are influenced by teacher performance. Kompas.Com (2019) conveyed "the results of a survey conducted by the Indonesian Teachers Association (PGRI) 
regarding the impact of teacher professional certification on teacher performance. Of the 28 provinces studied, the results turned out to be unsatisfactory. This source means that teacher performance needs to be improved again. In general, an indication of the importance of performance can also be seen from the existence of guidelines or the Work Implementation Assessment List (DP3). This assessment is a form of coaching in the field of education management and human resources, the implementation of which can be carried out periodically, continuously, and continuously (Kuncoro \& Dardiri, 2018).

One factor influencing performance is work motivation. As Putro (2015) said that motivation plays an essential role in changing worker behavior. Factors that affect individual performance are motivation. A person's abilities can be determined by skills and knowledge, while reason can influence skills. Basis can change the energy in a person to be more enthusiastic in carrying out their duties and responsibilities.

Additionally, Riyadi \& Mulyapradana's (2017) research indicates that work motivation has a favorable and statistically significant effect on teacher performance. This suggests that if a teacher's work motivation increases, so does the teacher's routine, and vice versa. If a teacher's motivation for work deteriorates, his or her performance will deteriorate as well. Similar results were also found by Sutikno, Bagus P. Yudh (2018) in their research. Those who concluded that teacher performance or work performance had a close relationship with work motivation.

Being a teacher without work motivation will quickly feel bored because there is no driving element. Teachers who have motivation will have a passion for work, willing to work hard by donating all abilities, thoughts, skills to realize educational goals. Motivation is a potential power within a human being that he can cultivate and which can have a positive or bad effect on the outcomes of his performance (Fuad \& Srimindarti, 2015).

In addition to work motivation, teachers also need commitment. Teacher commitment is defined as a measure of the strength of a teacher's identification with school goals and values and being involved in it; organizational commitment is also a better indicator for teachers who want to stay in their jobs or want to move. Commitment to the school also discusses the closeness of teachers to the school where they are located, and at the same time, commitment reflects the strength of teacher involvement and loyalty to the school (Wibowo, 2009). Commitment has a positive effect on teacher performance. Commitment serves as the shaper of: (1) individual values and norms; (2) self-control; (3) forming attitudes and responsibilities for teachers in carrying out the teaching and learning process so that they can carry out their primary tasks well (Purwoko, 2018). This means that in carrying out tasks with a lack of commitment, teachers will look like, coming to school late, not caring about the school environment, being ignorant to students, and not wanting to improve their ability to become creative, innovative, and inspiring teachers. This will have an impact on the quality of students to below. High teacher commitment will usually increase high achievement and, at the same time, can reduce 
absenteeism, and vice versa. If a teacher has a low level of commitment, then his achievement is also joint (Damanik, 2019).

This research is significant to do to determine whether work motivation and commitment significantly affect teacher performance.

\section{B. METHOD}

This study uses a quantitative approach with a correlational type. However, in this study also uses enrichment with statistics descriptive for certain things that are needed. The initial step (entry point) of research is to use descriptive analysis tools as the initial basis for the analysis. Thus the examination begins by looking at the tendency of the relationship between the observed phenomena after a descriptive quantitative approach is carried out through the distribution of questionnaires. Further analysis is carried out by looking at the relationship of phenomena which is carried out using statistical analysis.

This research is in Nanga Pinoh District, Malawi Regency, West Kalimantan Province, namely Satate High School 1 Nanga Pinoh, Malawi Regency. The population in this study were all teachers of Satate High School 1 Nanga Pinot. The number of teachers of Satate High School 1 Nanga Pinot is 43 people, so the samples taken in this study were 43 samples. According to Tersiana, A. (2018:78), determining the model that if the subject is less than 100, then everything is taken to be the research sample. This is the population and sample in this study.

The operational definition of the research contains a brief understanding and indicators of each variable that then these indicators are processed into statement items on the instrument study. The quick understanding and indicators of each research variable are described below:

Table 1. Description of Variables, Operational Definitions, and Research

$$
\text { Indicators }
$$

\begin{tabular}{|c|c|c|}
\hline Research variables & Operational definition & Indicator \\
\hline Work Motivation $(\mathrm{Y})$ & $\begin{array}{l}\text { The driving force is the } \\
\text { driving force from } \\
\text { within a person to do or } \\
\text { carry out work, duties, } \\
\text { and responsibilities. }\end{array}$ & $\begin{array}{l}\text { 1. Have a sense of responsibility towards } \\
\text { work } \\
\text { 2. Have a high interest in work } \\
\text { 3. Have satisfaction at work } \\
\text { 4. There is a need that must be met } \\
\text { 5. Passion at work } \\
\text { 6. Getting praise or attention from others } \\
\text { 7. Want to get a salary or incentives } \\
\text { 8. Desire to get award or achievement } \\
\text { 9. There is encouragement from superiors } \\
\text { 10. Interpersonal relations and working } \\
\text { conditions }\end{array}$ \\
\hline Commitment (X1) & $\begin{array}{l}\text { Firmness or } \\
\text { determination to give } \\
\text { time, energy, and } \\
\text { thoughts for the } \\
\text { betterment of the } \\
\text { institution education in }\end{array}$ & $\begin{array}{l}\text { 1. Have high loyalty to the school where you } \\
\text { teach } \\
\text { 2. Feeling happy as a teacher } \\
\text { 3. Have a determination based on the } \\
\text { intention to serve } \\
\text { 4. Considering the advantages of continuing }\end{array}$ \\
\hline
\end{tabular}




\begin{tabular}{|c|c|c|}
\hline & a broad sense & $\begin{array}{l}\text { to teach at school } \\
\text { 5. Calculating the loss if you leave school } \\
\text { 6. Have a will to work } \\
\text { 7. Responsibility in advancing the school } \\
\text { where you teach }\end{array}$ \\
\hline Performance (X2) & $\begin{array}{l}\text { The results or level of } \\
\text { success achieved by a } \\
\text { teacher in the field of } \\
\text { her job according to } \\
\text { specific criteria and } \\
\text { evaluated by certain } \\
\text { people, especially } \\
\text { supervisors } \\
\text { principals }\end{array}$ & $\begin{array}{l}\text { 1. Understand students well and correctly } \\
\text { 2. Able to plan lessons well } \\
\text { 3. Able to implement, evaluate and assess } \\
\text { student learning outcomes } \\
\text { 4. Have competence in classroom } \\
\text { administration and learning } \\
\text { 5. Have competence in student development } \\
\text { 6. Have a steady, stable, mature, wise, } \\
\text { authoritative attitude. } \\
\text { 7. Can be a role model for students } \\
\text { 8. Mastering materials, learning theories, } \\
\text { learning methods, learning media, and } \\
\text { educational foundations. } \\
\text { 9. Able to apply various learning methods } \\
\text { and learning media } \\
\text { 10. Can shape the personality or character of } \\
\text { students } \\
\text { 11. Have the ability to maintain relationships } \\
\text { with students } \\
\text { 12. Have the ability to maintain relationships } \\
\text { with fellow educators, parents or } \\
\text { guardians of students, and the community }\end{array}$ \\
\hline
\end{tabular}

Source: Data Proceed

Questionnaires or questionnaires were employed to collect data. Multiple Linear Regression was used to examine the data gathered using the SPSS for Windows Version 22 application. According to the regression equation, the variable relationship model will be interpreted: $Y=a+b 1 X 1+b 2 X 2+E$ Where: $Y=$ Teacher's work performance.

\section{RESULTS AND DISCUSSION}

\section{Classic Assumption Test}

Regression equation models can be analyzed and give good results representative if it is BLUE (Best Linear Unbiased Estimation) or the classical assumption has been tested. This study's classical assumption testing performed on the regression equation model includes the classical assumption test of multicollinearity, heteroscedasticity, and normality.

\section{a. Test Multicollinearity}

To determine multicollinearity, the regression model must be correlated with the independent variables. A well-designed regression model should not connect variables in isolation. If the independent variables are related to one another, they are not orthogonal. The term "variable orthogonal" refers to an independent variable whose correlation coefficient with other independent variables is equal to zero 
(Ghozali, 2018). To determine the presence or absence of multicollinearity, if the VIF value is less than 10.00 and the tolerance value is not less than or greater than 0.1 . This means that multicollinearity does not exist (Ghozali, 2018). Test results multicollinearity can be seen in the following table.

Table 2. Correlation Coefficient between Independent Variables

Coefficients

\begin{tabular}{|c|c|c|c|c|c|c|c|c|}
\hline \multirow{2}{*}{\multicolumn{2}{|c|}{ Model }} & \multicolumn{2}{|c|}{$\begin{array}{c}\text { Unstandardized } \\
\text { Coefficients }\end{array}$} & \multirow{2}{*}{$\begin{array}{c}\text { Standardized } \\
\text { Coefficients } \\
\text { Beta } \\
\end{array}$} & \multirow[b]{2}{*}{$\mathrm{t}$} & \multirow[b]{2}{*}{ Sig. } & \multicolumn{2}{|c|}{ Collinearity Statistics } \\
\hline & & B & $\begin{array}{l}\text { Std. } \\
\text { Error }\end{array}$ & & & & Tolerance & VIF \\
\hline 1 & (Constant) & 15,338 & 10,768 & & 1.424 & .162 & & \\
\hline & $\mathrm{X} 1$ & .411 & .188 & .302 & 2.185 & .035 & .973 & 1.028 \\
\hline & $\mathrm{X} 2$ & .645 & .247 & .360 & 2,608 & .013 & .973 & 1.028 \\
\hline
\end{tabular}

a. Dependent Variable: $Y$

Table 5.13 shows that X1 VIF value of $1.028<$ from 10.00 and a tolerance value of 0.973 > from 0.1 and X2 VIF value of $1.028<$ from 10.00 and a tolerance value of $0.973>$ from 0.1 then it means that it does not happen multicollinearity.

b. Auto Correlation Test

This test is used to determine whether or not the linear regression model contains autocorrelation. A good regression model is one that is autocorrelation-free. To determine it, the calculated Durbin Watson value is compared to the Durbin Watson table value using a 5\% significance level. The table value is the number of samples (n) and the number of independent variables (k). If the calculated value is more significant than the table value, the calculated value is greater than the table value. Less than the total $(4-\mathrm{du})$ indicates that no autocorrelation exists (Ghozali, 2018). The following table summarizes the autocorrelation test results:

Table 3. Calculated Value of Durbin Watson

\begin{tabular}{|l|r|r|r|r|c|}
\hline Model & R & R Square & $\begin{array}{c}\text { Adjusted R } \\
\text { Square }\end{array}$ & $\begin{array}{c}\text { Std. The error of } \\
\text { the Estimate }\end{array}$ & $\begin{array}{l}\text { Durbin- } \\
\text { Watson }\end{array}$ \\
\hline 1 & $.507 \mathrm{a}$ & .257 & .220 & 1.68673 & 2.189 \\
\hline
\end{tabular}

a. Predictors: (Constant), X2, X1

b. Dependent Variable: $Y$

Table 3 shows that Durbin Watson's arithmetic value is 2,189 greater than $>$ score table 1.6091, and less than the value $(4-\mathrm{du}) 4-1.6091=2.3909$ means that there is no autocorrelation.

c. Test Heteroscedasticity

This test may be identified by examining the graph plot between the dependent variable's predicted value (ZPRED) and the residuals (SSID). Detect heteroscedasticity by looking for a pattern-specific and graphic scatterplot between SRESID and ZPRED, where the $\mathrm{Y}$-axis represents the predicted $\mathrm{Y}$ and the $\mathrm{X}$-axis represents the studentized predicted residual ( $Y$ indicated - actual $Y$ ). 


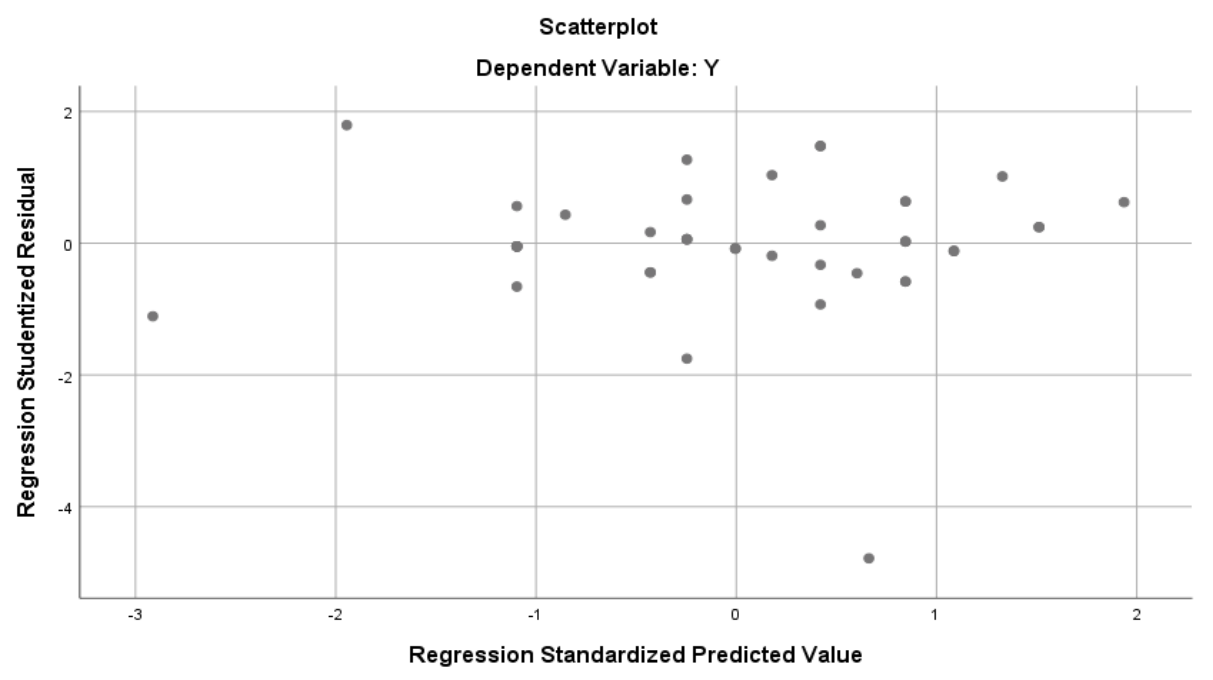

Figure 1. Scatterplot Diagram

As illustrated in the scatter plot graph above, the points spread randomly and are distributed both above and below the Y-axis zero. This is not the case. Heteroscedasticity on the regression model, allowing for the possibility of using the regression model to predict teacher performance.

d. Normality test

Graph analysis is a simple approach to determine the residuals' normality by examining the standard probability plot, which compares a straight diagonal line to the residual data. If the residual data distribution is normal, the points describing the actual data will follow the diagonal line (Ghozali, 2018). The following figure illustrates the normalcy test:

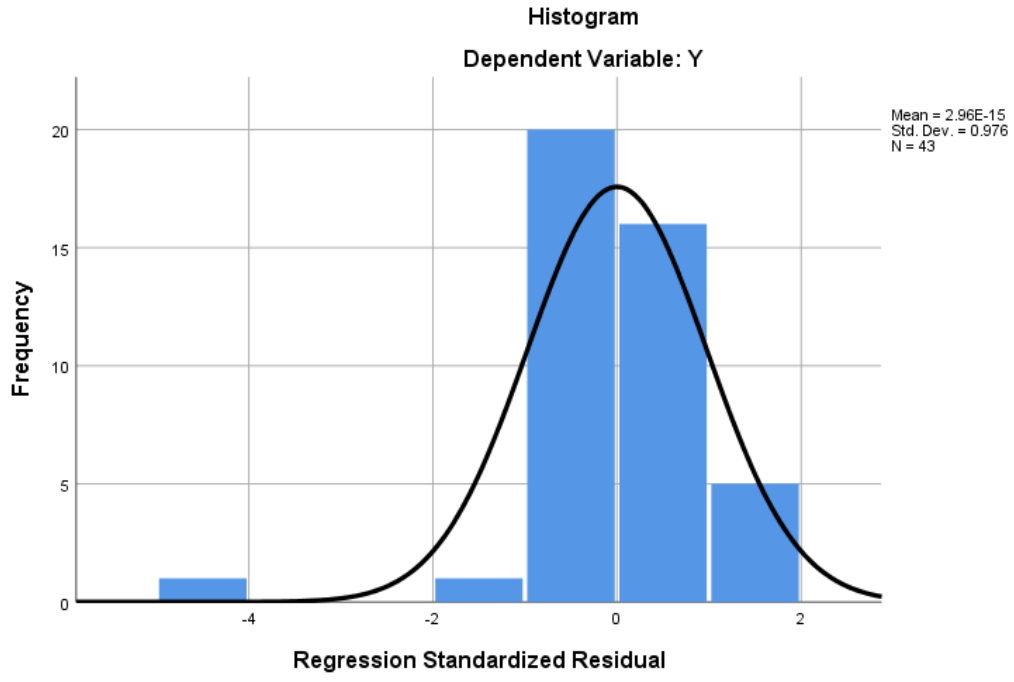

Figure 2. Histogram 


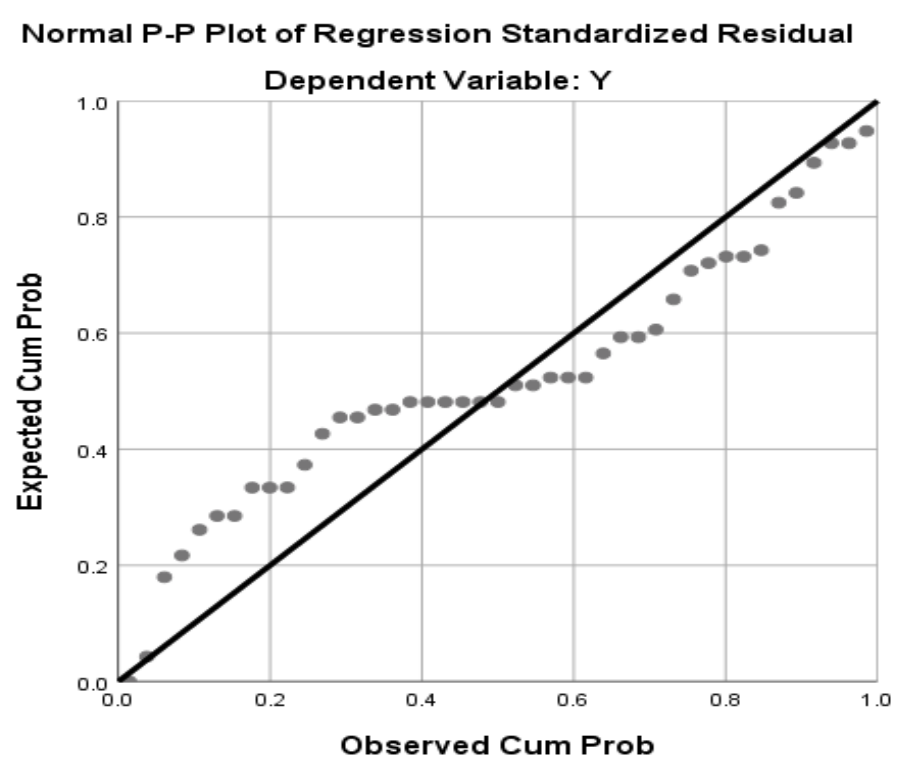

Figure 3. Plot Normal Graph

By comparing the histogram graph to the standard plot graph, it is clear that the histogram graph exhibits a distribution pattern that is close to normal. While the standard plot graph shows the dots spread out around the diagonal line in the direction of the diagonal line, the standard plot graph shows the dots spread out in the other direction. These two graphs demonstrate that the regression model is possible since it adheres to the normality assumption.

\section{Regression Analysis Results}

Regression analysis is used to predict a dependent variable $(\mathrm{Y})$ based on a variable $(X)$ in a linear equation. Based on the data obtained from 43 respondents, the research results were discussed, among others, using simple linear regression analysis and analysis regression multiple linear. As for the calculation of the regression analysis using the SPSS version 25 assistance program.

a. Work Motivation Variables on Teacher Performance

From the output results in the attachment, regression analysis variable work motivation on teacher performance, then each coefficient predictor and constants as follows:

$\mathrm{a}=32,720$

$\mathrm{b}=0.492$

Then the regression equation is:

$\mathrm{Y}=\mathrm{a}+\mathrm{bX1}$

$\mathrm{Y}=32.720+0.492 \mathrm{X} 1$

Where:

$\mathrm{X} 1=$ Work Motivation Variable

$\mathrm{Y}=$ Teacher performance

The interpretation of the regression equation above can be concluded that the coefficient (b) is called the regression direction coefficient, which states the change in the average variable $(\mathrm{Y})$ for each change in the variable $(\mathrm{X} 1)$ by one unit. If the 
coefficient (b) is positive, there is an increase of one team from the value of coefficient (b), and if it is negative, there is a decrease of one unit from the coefficient value (b).

1) The constant value (a) is 32,720 . If there is no work motivation value $(X)$, then the teacher's performance value is (Y) 32,720.

2) The regression coefficient of the work motivation variable (X1) is 0.492, which states that for every additional value of the work motivation variable (X1), the teacher's performance value (Y) increases by 0.492 . Because the coefficient value of the work motivation variable (X1) is positive, an additional one unit of the work motivation variable (X1) will increase teacher performance by 0.492 units and vice versa if the work motivation variable $(\mathrm{X} 1)$ decreases by one team, it will result in a reduced teacher performance of 0.492 units.

b. Variable Commitment to Teacher Performance

From the output results in the attachment, regression analysis of the commitment variables on teacher performance, then each coefficient predictor and constants as follows:

$\mathrm{a}=31.152$

$\mathrm{b}=0.735$

Then the regression equation is:

$\mathrm{Y}=\mathrm{a}+\mathrm{bX2}$

$\mathrm{Y}=31152+0.735 \mathrm{X} 2$

Where:

X2 = Commitment Variable

$\mathrm{Y}=$ Teacher Performance

Interpretation from the regression equation above, it can be concluded that the coefficient (b) is called the regression direction coefficient, which states the change in the average variable $(Y)$ for each change in the variable (X2) by one unit. If the coefficient (b) is positive, there is an increase of one team from the value coefficient (b), and if it is negative, there is a decrease of one unit from the coefficient value (b).

1) The constant value (a) is 31,152 . If there is no commitment value (X2), then the teacher's performance value is (Y) 31,152.

2) The regression coefficient for the commitment variable $(X 2)$ of 0.735 states that for every additional value of the commitment variable $(X 2)$, the teacher's performance value $(Y)$ increases by 0.735 . Because the coefficient value of the commitment variable $(\mathrm{X} 2)$ is positive, the addition of one unit of the commitment variable (X2) will increase teacher performance by 0.735 units and vice versa if the commitment variable $(X 2)$ is reduced by one team, the teacher's routine will decrease by 0.735 units.

c. Variables of Work Motivation and Commitment to Teacher Performance 
From the output results in the appendix, regression analysis of work motivation variables and commitment variables on teacher performance variables, then each coefficient predictor and constants as follows:

$$
\begin{aligned}
& a=15.338 \\
& b 1=0.411 \\
& b 2=0.645
\end{aligned}
$$

Then the regression equation is:

$\mathrm{Y}=\mathrm{a}+\mathrm{b} 1 \mathrm{X} 1+\mathrm{b} 2 \mathrm{X} 2$

$\mathrm{Y}=15.338+0.411 \mathrm{X} 1+0.645 \mathrm{X} 2$

Information:

$\mathrm{A}=$ Constant

b1 $=$ Coefficient

b2 = Coefficient

$\mathrm{X} 1=$ Work Motivation Variable

$\mathrm{X} 2$ = Commitment Variable

$\mathrm{Y}=$ Teacher Performance

The interpretation of the multiple regression equation above is as follows:

1) The constant value (a) is 15.338. If there is no work motivation (X1) and commitment $(\mathrm{X} 2)$ value, then the teacher's performance value is $(\mathrm{Y})$ 15.338.

2) The value of the work motivation coefficient (X1) of 0.411 indicates if the work motivation variable changes by one unit with the assumption that the commitment variable (X2) is fixed, it results in a change in teacher performance of 0.411 units. Because the coefficient value of the work motivation variable is positive, an additional one branch of the work motivation variable will increase teacher performance by 0.411 units, and vice versa. If the work motivation variable is reduced by one team, it will minimize teacher performance of 0.411 units.

3) The value of commitment (X2) of 0.645 indicates that if the commitment variable changes by one unit with the assumption that the work motivation coefficient variable $(X 1)$ is constant, it changes teacher performance by 0.645 units. Because the coefficient value of the commitment variable is positive, the addition of one team of the commitment variable will increase teacher performance by 0.645 units and vice versa. If the commitment variable is reduced by one unit, it will minimize teacher performance of 0.645 units.

\section{Hypothesis Test}

Based on the data obtained from 43 respondents, the discussion of the research results was carried out to test the hypotheses that had been put forward using the SPSS version 25 program. The complete analysis results can be seen in the appendix, while briefly it is given as follows: 


\section{a. Hypothesis 1}

Based on the results of calculations using the SPSS Version 25 program and the size of the correlation coefficient $(R)$ of +0.361 , it is possible to conclude that there is a relationship between work motivation and teacher performance, as indicated by the positive value $(R)$.

If the t-table alpha is $5 \%$ and the sample size is 43 respondents, the obtainedtable value is 1.681. The calculated findings indicate that the $t$-count value is +2.482 . When compared to the $t$-table value of 1.681 , the $t$-count $>t$-table with a probability of sig $=0.0170 .05$, indicating that work motivation has a substantial effect on teacher performance.

The level of work motivation's influence is indicated by the coefficient of determination (R2) of 0.361 , which indicates that the independent variable, work motivation (X1), has a 36.1 percent effect on the dependent variable, teacher performance $(\mathrm{Y})$. In comparison, the remainder is impacted by external influences.

b. Hypothesis 2

Based on the results of calculations using the SPSS Version 25 program and the magnitude of the correlation coefficient $(R)$ of +0.410 , it can be concluded that there is a relationship between teacher dedication and performance, as indicated by the positive value $(R)$.

If the t-table alpha is $5 \%$ and the sample size is 43 respondents, the obtainedtable value is 1.681 . The calculated findings indicate that the $t$-count value is +2.881 . When compared to the t-table value of 1.681 , the $t$-count $>$ t-table with probability $\operatorname{sig}=0.0060 .05$, indicating that commitment has a substantial effect on teacher performance.

The degree of the commitment effect is indicated by the coefficient of determination (R2) of 0.410 , which indicates that the independent variable, commitment (X2), has a 41.0 percent effect on the dependent variable, teacher performance $(\mathrm{Y})$. In comparison, the remainder is impacted by external influences.

c. Hypothesis 3

From the results of calculations with the help of the SPSS Version 25 program by taking into account the magnitude of the correlation coefficient $(R)$ of +0.507 , it can be stated that there is a simultaneous relationship between work motivation and commitment to teacher performance seen from the value $(\mathrm{R})$ which is positive. This means that the increasing work motivation and commitment together will be able to improve teacher performance.

The F-Table Alpha value is 5\%, and the number of samples is 43 respondents obtained-table a value of 3,214. Based on the calculation results, the F-count value is +6.917 , and when compared with the F-table value of 3.214, the F-count $>$ F-table with probability sig $=0.003<0.05$ so that the effect of work motivation and commitment simultaneously on teacher performance is stated significantly.

The magnitude of the effect of work motivation and commitment simultaneously can be seen from the coefficient of determination (R2) of 0.507, which implies that the extent of the influence of the independent variables, namely 
work motivation (X1) and commitment (X2), simultaneously on the dependent variable of teacher performance $(\mathrm{Y})$ is equal to $50.7 \%$. In contrast, the rest is influenced by other factors.

According to the findings of the study, work motivation and dedication benefit teacher performance at Satate High School 1 Nanga Pinot. Increased teacher motivation at Satate High School 1 Nanga Pinoh will have a positive effect on teacher performance at Satate High School 1 Nanga Pinot. Similarly, with commitment, increasing teacher responsibility at Satate High School 1 Nanga Pinoh will result in increased teacher performance at Satate High School 1 Nanga Pinoh, and vice versa.

These results follow the study results of Pramono \& Suddin (2011) and Sukamto \& Pardjono (2016) in their research on the effect of motivation and commitment on employee performance. The explanation has been empirically confirmed as the primary driver of employee performance (Kwapong, Opoku \& Donyina, 2015). Employee performance variable of $73.5 \%$ is influenced by motivation variable (Paais \& Pattiruhu, 2020). Other research was conducted by Riyanto (2011), Erlangga \& Erlangga (2021), which also concluded that partially motivation has a significant and positive effect on performance teachers.

The study's findings indicate that both motivation and commitment have a favorable effect on teacher performance. Work motivation has a limited effect on teacher performance, whereas commitment has a limited effect on teacher performance.

As can be observed, boosting teacher motivation and commitment will result in increased teacher performance and vice versa. According to Abas (2017), work motivation is the driving force that motivates an individual to be willing and able to move the ability to develop skills and abilities in energy and time management in order to carry out various activities that are their responsibility and fulfill their obligations to achieve predetermined goals. With job motivation, employees desire to work diligently and joyfully to get the best results possible. According to Wagiran (2019), commitment refers to the direction of a functional relationship between individuals and their organizations. As a result, individuals are willing to labor with complete loyalty of their own volition.

\section{CONCLUSION}

Based on the results of the data and research analysis, it can be concluded that: 1) Work motivation has a significant effect on the performance of Satate High School 1 Nanga Pinoh teachers by $36.1 \%$, with the regression equation $\mathrm{Y}=$ $32.720+492 \times 1$. This means that the higher the work motivation of the teacher, the better the teacher's performance. On the other hand, the lower the work motivation, the less good the teacher's performance; 2) Commitment has a significant effect on the performance of Satate High School 1 Nanga Pinoh teachers by $41.0 \%$, with the regression equation $\mathrm{Y}=31,152+735 \mathrm{X} 2$. This means that the higher the teacher's motivation, the better the teacher's performance. On the other hand, the lower the 
commission, the less good the teacher's performance; and d) There is a significant simultaneous effect between work motivation and commitment to teacher performance at Satate High School 1 Nanga Pinoh of 50.7\% with the regression line equation $Y=15.338+411 X 1+645 X 2$. This means that the higher the work motivation and commitment, the better the teacher's performance. On the other hand, the lower the work motivation and commitment of the teacher, the less good the teacher's performance.

\section{REFERENCES}

1. Abas, E. (2017). The Principal of Madrasah Leadership Magnets on Teacher Performance. Jakarta: Elex Media Komputindo.

2. Anwar, H., Defawati, Y., Demina, M., \& Marsidin, S. (2021). Analysis of the Effect of Motivation on Individual (Teacher) Performance. JIRA: Journal of Academic Innovation and Research, 2(7), 1087-1095.

3. Damanik, B. E. (2019). The Influence of Motivation and Commitment to Improving Teacher Work Achievement. Journal of Economics and Business (EKEBI), 2(1), 178-188.

4. Erlangga, S., \& Erlangga, H. (2021). The Influence of Motivation, Ability, Organizational Culture, Work Environment on Teachers Performance. Turkish Journal of Computer and Mathematics Education, 12(4), 99-108.

5. Fuad, S., \& Srimindarti, C. (2015). The Effect of Motivation and Organizational Commitment on Teacher Performance Moderated by Organizational Culture in Noodles in Winona District, Pati District (Case Study on Noodle Teachers in Winona District, Pati District).

6. Ghozali, I. (2018). Application of Multivariate Analysis with the SPSS 25 IMB Program. Semarang: Diponegoro University.

7. Government Regulation of the Republic of Indonesia Number 19 of 2017 concerning amendments to Government Regulation Number 74 of 2008 regarding Teachers.

8. Kompas.com. (2019). Low Teacher Performance. Retrieved from https://national.kompas.com/read/2019/10/07/02424962/twitter.com

9. Kuncoro, T., \& Dardiri, A. (2017). Teacher performance and work environment in the instructional process in a vocational school. In AIP Conference Proceedings (Vol. 1887, No. 1, p. 020043). AIP Publishing LLC.

10. Kwapong, L. S. A., Opoku, E., \& Donyina, F. (2015). The effect of motivation on the performance of teaching staff in Ghanaian polytechnics: The moderating role of education and research experience. Global Journal of Human Resource Management, 3(6), 30-43.

11. Meiliyani, R., Fitria, H., \& Puspita, Y. (2021). The Effect of Teacher Certification and Performance on Student Achievement. Journal of Education Research, 2(1), 614. 
12. Paais, M., \& Pattiruhu, J. R. (2020). Effect of motivation, leadership, and organizational culture on satisfaction and employee performance. The Journal of Asian Finance, Economics, and Business, 7(8), 577-588.

13. Pramono, A., \& Suddin, A. (2011). Effect of Emotional Intelligence and Organizational Commitment on Teacher Performance with Work Motivation as Moderating Variable. JournalManagement Human Resources, 5, 54-64.

14. Putro, GS (2015). Factors Affecting Teacher Performance in Implementing the Teaching and Learning Process at SMPN 5ButtonPao, Gowa Regency. AKMEN Scientific Journal, 12(1), 100-114.

15. Riyadi, S., \& Mulyapradana, A. (2017). The Effect of Work Motivation on Teacher Performance Radhatul Atfal in Pekalongan City. Pekalongan City Research and Development Journal, 13.

16. Riyanto, S. (2017). Effect of motivation and job satisfaction on teachers' performance in Mentari School Bintaro (MSB). Targets, 83, 91.

17. Sukamto, Y., \& Pardjono, P. (2016). The influence of teacher competence, work commitment, and work motivation on the performance of the Mainstay Junior High School teacher in Sleman. Journal of educational science research, 9(2), 165-178.

18. Wagiran. (2019). Educational Research Methodology Theory and Its Implementation.

19. Widoyoko, E. P. (2009). Analysis of the Influence of Teacher Performance on Student Learning Motivation. Upper Journal of Education, 1-16. 